African J. Biol. Sci., 14 (2): 91-102 (2018)

ISSN 1687-4870

www. ajbs.journals.ekb.eg

e- ISSN 2314-5501 (online)

E.mail: aasdjournal@yahoo.com

\title{
Can Serum Iron Parameters Represent Surrogate Markers for Chronic Hepatitis C-Based Hepatocellular Carcinoma?
}

\author{
Lamiaa Abdel-Latif ${ }^{1}$, Gamal E Shihaa ${ }^{2,3}$, Waleed Samir ${ }^{4}$ and Elsayed E A Toson ${ }^{1}$
}

1- Chemistry Department, Faculty of Science, Port Said University, Port Said, Egypt.

2- Internal Medicine Department, Faculty of Medicine, Mansoura Univ., Mansoura, Egypt.

3- Egyptian Liver Research Institute and Hospital (ELRIAH), Sherpin, Aldakahlia, Egypt.

4- Specialized Internal Medicine Hospital, Faculty of Medicine, Mansoura Univ., Egypt.

\begin{abstract}
Iron homeostasis is of critical for human life. The pathogenesis of its accumulation in chronic hepatitis $\mathrm{C}(\mathrm{CHC})$ virus is not yet completely understood. Objectives: The aim is to investigate the possible correlations between serum metabolic markers of iron, HCV viral load, total micro-RNA-cDNA and the progression of liver disease into hepatocellular carcinoma (HCC). Patients and methods, A total of 126 patients with chronic hepatitis $\mathrm{C}$ virus were included in this study. Of them 22 patients were with $\mathrm{HCC}$ and 44 were CHC patients without HCC. In addition, a group of 30 healthy individuals were included and was served as control group. RNA was extracted and total microRNA was converted into-cDNA and was determined by nanoQuant, iron status with standard assay techniques. HCV antibodies were evaluated by enzyme linked immunosorbent assay (ELISA) and HCV-RNA by real time polymerase chain reaction (RT-PCR). Alpha-fetoprotein, routine liver function tests, international normalization ratio (INR) and platelets count were also done. Beside, HCV-related $\mathrm{HCC}$ were radiologically proved via abdominal US and Triphasic abdominal CT. Results: Markers of iron metabolism; including iron and ferritin were dramatically increased in sera of HCC patients compared with those of the non-HCC group. Conversely, the mean TIBC level was highly reduced in sera of HCC patients' group compared with that of the non-HCC individuals. Significant and positive correlations were found between the individual levels of iron markers with serum liver enzymes and bilirubin. On the other hand, negative correlations were found between the levels of these markers with both albumin and platelets, especially in the blood of HCC patients. Total miRNAcDNA and viral RNA showed no significant difference among the two groups but the level of the former was significantly lowered in sera of HCC patients compared with those of the control group. In conclusion, these results suggest that serum markers of iron mediate liver disorders; especially $\mathrm{HCC}$ and can represent surrogate markers for the severity of such disorders. Also, the role viral molecules and/or micro-RNA in iron overload must not be neglected.
\end{abstract}

Key words: HCC, INR, TIBC and RT-PCR.

\section{INTRODUCTION}

In addition to causing liver diseases, chronic hepatitis $\mathrm{C}$ has a broad spectrum of extra-hepatic manifestations. Also, patients with long-lasting $\mathrm{HCV}$ infection are at major risk of developing hepatocellular carcinoma (HCC) (Dedania and $\mathrm{Wu}, 2015$ ). Liver is the main iron reservoir in the body (Franchini et al., 2008; Vagu et al., 2013). Also, liver plays a fundamental role in iron metabolism. CHC infection frequently accumulates iron in the liver which may participate in liver injury and worsens its severity (Metwally et al., 2004) via the Fenton reaction producing 


\section{Lamiaa Abdel-Latif et al.}

hydroxyl radicals (Fenton, 1894).These initiate a radical reaction that will ultimately damage the liver cells (Khare and Garg , 2015). Ferritin is an acute phase protein and its levels will be elevated in response to iron overload and systemic inflammation (Khare and Garg, 2015). Ferritin synthesis is induced by macrophages, and hepatocytes. Raised ferritin levels can be seen in iron overload conditions, inflammation and liver diseases (Walker et al., 2010).

The results of clinical studies which were designed to assess the impact of liver iron content on the risk of tumor development have remained controversial for some time. Further, it is known that common factors can affect both liver iron overload and the risk of cancer. Zhou et al. (1988) added that, the mechanisms underlying hepatic iron accumulation in chronic hepatitis $\mathrm{C}$ have not been fully elucidated. Reduction of the hepcidin transcription activity by hepatitis $\mathrm{C}$ virus (HCV)-induced reactive oxygen species (ROS) may in part account for iron loading, but the regulation of hepcidin is very complex and may depend on many variables, including the particular stage of the systemic and/or hepatic inflammatory conditions and the circulating transferrin-bound iron and intracellular iron stores. This might explain the variations in hepatic iron concentrations reported among patients with $\mathrm{HCV}$-related chronic liver disease. However, even mild-to-moderate iron overload in the liver contributes to disease progression and hepatocarcinogenesis in chronic hepatitis $\mathrm{C}$. Low hepcidin levels have been shown to trigger hepatic iron accumulation in these patients (Emerit et al., 2001). HCV suppresses hepcidin expression, increasing duodenal iron transport and macrophage iron release (Kohgo et al., 2007).

At the molecular level, hepcidin binds to ferroportin, an iron exporter which are expressed by enterocytes and macrophages. Upon binding, induction of ferroportin internalization and degradation starts, thus preventing iron entry into plasma (Lavanchy, 2011). Such prevention enables the reduction of iron entry in the plasma compartment (Jaroszewicz et al., 2010); De Domenico, 2009). Uchino et al. (2016) showed that both extremely high and low serum ferritin level was an independent risk factor for development of $\mathrm{HCC}$ in male patients with chronic hepatitis C. Uchino et al. (2018) reported that serum levels of ferritin were correlated with pathological iron deposition. However, such level was not a predictor of recurrence or survival among patients with HCC undergoing radiofrequency ablation (RFA).

Low level of hepcidin leads to iron overload which lead to inflammation and liver fibrosis (Hör and Schmidt, 2014). Studies in animal and in cellular models have suggested that HCV infection may directly modulate hepcidin expression by $\mathrm{HCV}$-induced reactive oxygen species (ROS) (Castagna et al., 2010).

\section{MATERIALS AND METHODS Patients and Blood sampling: Patients:}

This analytical retrospective study was performed on patients selected from the outpatient hepatology clinics and HCC early detection clinic, in Egyptian Liver Research Institute and Hospital (ELRIAH), Sherpin, Aldakahlia, Egypt, from April 2016 to April 2017. The study has been conducted on 22 Patients with HCC, about 100 patients without HCC (Fibrotic and cirrhotic patients) and 30 individual as control group. All patients tested positive for hepatitis $\mathrm{C}$ antibodies (HCV-Ab) and were negative for other chronic liver diseases. They had normal kidney function, normal glucose with no liver transplantation. None of the patients had received antiviral treatment 


\section{Can Serum Iron Parameters Represent Surrogate Markers for Chronic Hepatitis C-Based Hepatocellular Carcinoma?}

before liver Fibroscan and blood sampling. The exclusion criteria were patients with positive results for screening tests for other viral hepatitis infections (anti-HAV IgM, HBsAg, anti-HBc IgM) or HIV infection, hematological or non-viral chronic liver diseases, and patients previously treated for HCV infection. No formal sample size calculation was performed, all the study patients had to have active viral replication confirmed by detecting HCV-RNA, using real-time polymerase chain reaction assay (COBAS Taqman HCV Test, Roche.

\section{Blood sampling:}

Six ml venous blood sample were withdrawn from each individual; of whom:

\section{Serum sample collection:}

Four milliliters of venous blood were obtained, left to clot, centrifuged and the serum fraction was separated and either freshly used or stored at $-80{ }^{\circ} \mathrm{C}$ until used.

Plasma sample collection:

$2 \mathrm{ml}$ whole blood was poured onto EDTA.

\section{Biochemical and immunological assays: Routine laboratory tests:}

Platelets count was done using Dcell 60 automated hematology analyzer (Sysmex X 1800 incorporation, Japan), Liver function tests including serum AST, ALT, albumin, bilirubin were done using automated Biochemistry analyzer (Cobas Integra 400, Roch, Switzerland).

Iron, ferritin and total iron binding capacity (TIBC):

Each of which was determined using standard assay method according to their individual enclosed pamphlets [Egyptian Company for Biotechnology (S.A.E), www.spectrum-diagnostics.com and email:info@spectrum-diagnostics.com] using automated Biochemistry analyzer (Cobas Integra 400, Roch, Switzerland).

Serological markers:

Serological markers for detecting $\mathrm{HCV}$ infection [hepatitis $\mathrm{C}$ antibodies (HCV Abs)] were estimated by ELISA (Merieux anti-HCV, version 4.0, Diasorin S.P.A. via Crescent no 13040 Saluggia (VC) - Italy).

\section{Molecular analysis}

RT-PCR for detecting HCV infection and cDNA-miRNA assays:

RNA extraction:

RNA was extracted from serum using QIAzol Lysis Reagent according to the manufacturer's instructions. The RNA purity was assessed by the RNA concentration and quantified by Nano Drop ND-1000 (Nanodrop, United States).

\section{HCV RNA quantization using RT-PCR:}

HCV RNA was quantized by quantitative RT-PCR using fully automated analyzer (Cobas amplified, Taqman48 analyzer, Roch Switzerland).

\section{Reverse transcription using miScript II RT Kit: \\ Only 5 x miScript HiSpec buffer had} been used for preparation of cDNA for realtime PCR with miScript miRNA PCR Arrays. Single-stranded cDNAs were generated using the RT kit according to the manufacturer's directions (miScript miRNA PCR system, miRneasy mini kit for miRNA extraction, miScript RT for miRNA reverse transcription). Further, total miRNA was assayed using nanoQuant.

\section{Fibroscan and Ultrasonography:}

Liver stiffness [expressed in kilopascals $(\mathrm{kPa})]$ was measured by transient elastography (Fibroscan; Echosens SA, Paris, France). The results obtained were ten valid readings with a success rate of at least $60 \%$ and an interquartile range 


\section{Lamiaa Abdel-Latif et al.}

under $30 \%$ of the median value. Fibroscan results ranges from 2.5 to $75 \mathrm{kPa}$. Healthy people without liver disease have a liver scarring reading less than $7.0 \mathrm{kPa}$ (median is $5.3 \mathrm{kPa}$ ). A person with chronic hepatitis $\mathrm{C}$ and a liver stiffness more than $14 \mathrm{kPa}$ has nearly a $90 \%$ probability of having cirrhosis, while patients with liver stiffness more than $7 \mathrm{kPa}$ have around an $85 \%$ probability of at least significant fibrosis. Patients were classified according to Fibroscan median into: F0 (no fibrosis, 0-5 kPa), F1 (minimal fibrosis without septa, 5.1- $7 \mathrm{kPa}$ ), F2 (moderate fibrosis with few septa, 7.1-10 $\mathrm{kPa}$ ), F3 (severe fibrosis with numerous septa but without cirrhosis, $10.1-17.5 \mathrm{kPa}$ ) and F4 (cirrhosis, 17.5-75 kPa).

\section{Statistical analysis:}

All statistical analyses were performed by Medcalc software (version 14.8.1.; Medcalc Software Bvba, Ostend, Belgium). Continuous variables were expressed as mean \pm standard deviation (SD). Comparisons of markers as well as routine laboratory tests and stages of fibrosis were analyzed using a two-sided $\mathrm{P}$ value. A value of $p<0.05$ was considered statistically significant. Person's correlation coefficient was used in establishing correlation among parameters.

\section{RESULTS}

1. Total miRNA-cDNA, iron, ferritin and total iron binding capacity (TIBC) and levels in sera of HCC patients and control group:

\subsection{Total MiRNA-cDNA levels:}

The mean level of total miRNAcDNA level of the control group was $31.7 \pm$ $6.6 \mu \mathrm{g} / \mathrm{dL}$ and that of HCC patients was 26.6 $\pm 6.2 \mu \mathrm{g} / \mathrm{dL}$. Thus, the mean difference was statistically and significantly lower than that of the control group $(\mathrm{P}<0.01$, Table 1$)$.

\subsection{Serum iron levels:}

The mean level of iron of the control group was $161.2 \pm 27.3 \mu \mathrm{g} / \mathrm{dL}$ and that of HCC patients was $203 \pm 30.6 \mu \mathrm{g} / \mathrm{dL}$. Thus, the mean difference was statistically and significantly higher than that of the control group $(\mathrm{P}<0.0001$, Table 1$)$.

\subsection{Serum ferritin levels:}

The mean level of ferritin of the control group was $72.2 \pm 41.9 \mu \mathrm{g} / \mathrm{dL}$ and that of HCC patients was $239.7 \pm 128 \mu \mathrm{g} / \mathrm{dL}$ which was statistically significantly higher in sera of HCC patients compared with that of the control group $(\mathrm{P}<0.0001$, Table 1$)$.

\subsection{Serum TIBC levels:}

The mean serum level of TIBC of the control group was $493.0 \pm 217.6 \mu \mathrm{g} / \mathrm{dL}$ and that of HCC patients was $298.4 \pm 108.1$ $\mu \mathrm{g} / \mathrm{dL}$. In general, TIBC of the HCC patients was found to be highly significantly decreased than that of the control group $(\mathrm{P}=0.0008$, Table1).

Table 1: Mean values of total miRNA-cDNA, iron, ferritin and total iron binding capacity (TIBC) in sera of HCC patients versus those of the control group:

\begin{tabular}{cccccc}
\hline Parameters & \multicolumn{3}{c}{ Control } & \multicolumn{2}{c}{ HCC patients } \\
\cline { 2 - 6 } Total miRNA-cDNA & $\mathbf{N}$ & Mean $\pm \mathbf{S D}$ & $\mathbf{N}$ & \multicolumn{2}{c}{ Mean $\pm \mathbf{S D}$} \\
Iron & 22 & $31.7 \pm 6.6$ & 21 & $26.6 \pm 6.2$ & $\mathrm{P}<0.01$ \\
Ferritin & 26 & $161.2 \pm 27.3$ & 22 & $203.0 \pm 30.6$ & $\mathrm{P} 1<0.0001$ \\
TIBC & 19 & $72.2 \pm 41.9$ & 22 & $239.7 \pm 127.8$ & $\mathrm{P} 1<0.0001$ \\
& 16 & $493.0 \pm 217.6$ & 22 & $298.4 \pm 108.1 \quad \mathrm{P}=0.0008$ \\
\hline
\end{tabular}

Values were expressed as mean \pm standard deviation (mean $\pm \mathrm{SD}$ ), $\mathrm{n}=$ number, $\mathrm{p}=$ probability (Significance Level) when HCC patients were compared to control group, $\mathrm{HCC}=$ hepatocellular carcinoma and miRNA- cDNA= microRNA-complementary DNA. 
2. Liver function markers, platelets and alpha-fetoprotein (AFP) levels in sera of HCC patients and control group:

There were significant differences between control group and HCC patients with respect to their mean values of SGPT, SGOT, S. albumin, total bilirubin, count of platelets and alpha fetoprotein levels (Table 2).

Table 2: Mean values of the liver function markers, platelets count and alpha-fetoprotein (AFP) levels in sera of HCC patients versus those of the control group:

\begin{tabular}{cccccc}
\hline Parameters & \multicolumn{2}{c}{ Control group } & \multicolumn{3}{c}{ HCC patients } \\
\cline { 2 - 6 } & $\mathbf{N}$ & Mean $\pm \mathbf{S D}$ & $\mathbf{N}$ & \multicolumn{2}{c}{ Mean \pm SD } \\
SGPT & 27 & $21.4 \pm 9.8$ & 21 & $64.8 \pm 38.6 \quad \mathrm{p}<0.0001$ \\
SGOT & 30 & $23.8 \pm 6.9$ & 22 & $82.7 \pm 31.7 \quad \mathrm{P}<0.0001$ \\
S. Albumin & 30 & $4.5 \pm 0.3$ & 22 & $3.6 \pm 0.6$ & $\mathrm{p}<0.0001$ \\
Total Bilirubin & 28 & $0.45 \pm 0.12$ & 21 & $1.4 \pm 0.9$ & $\mathrm{P}<0.0001$ \\
Platelets count & 28 & $254.6 \pm 55.9$ & 22 & $98.5 \pm 40.6 \quad \mathrm{P}<0.0001$ \\
Alpha fetoprotein & 21 & $2.8 \pm 0.5$ & 22 & $168.1 \pm 81.5 \mathrm{P}<0.0001$ \\
\hline
\end{tabular}

Values were expressed as mean \pm standard deviation (mean \pm SD), $n=$ number, $p=$ probability (Significance Level) when the results of patients with hepatocellular carcinoma (HCC) were compared to those of the healthy control group.

3. Mean total microRNA-cDNA and viremia levels in sera of $\mathrm{HCC}$ patients versus those of non-HCC patients:

As shown in Table (3), total miRNAcDNA levels were slightly decreased in sera of patients with HCC compared with that of nonHCC Patients. Viremia levels showed no statistically significant difference between these two groups of patients.

Table 3: Mean total microRNA-cDNA and viremia levels in sera of HCC patients versus those of non-HCC patients:

\begin{tabular}{ccccc}
\hline Parameters & \multicolumn{3}{c}{ Non-HCC patients } & \multicolumn{2}{c}{ HCC patients } \\
\cline { 2 - 6 } & $\mathbf{N}$ & Mean \pm SD & $\mathbf{N}$ & Mean \pm SD \\
Viremia & 63 & $5.5 \pm 0.91$ & 21 & $5.1 \pm 0.9 \quad$ P= NS \\
Total miRNA-cDNA & 49 & $29.7 \pm 10.8$ & 21 & $26.6 \pm 6.2 \quad$ P= NS \\
\hline
\end{tabular}

Values were expressed as mean \pm standard deviation (mean \pm SD), $n=$ number, $\mathrm{p}=$ probability (Significance Level), NS= non-significant and miRNA-cDNA= microRNA-complementary DNA.

4. Iron, ferritin and total iron binding capacity (TIBC) levels in sera of $\mathrm{HCC}$ patients and non-HCC patients:

4.1. Serum iron levels:

The mean level of iron of the non-
HCC patients were $173.3 \pm 25.3 \mu \mathrm{g} / \mathrm{dL}$ and that of HCC patients was $203 \pm 30.6 \mu \mathrm{g} / \mathrm{dL}$. Thus, the mean difference was statistically and significantly higher than that of the non-HCC patients $(\mathrm{P}<0.0001$, Table 4$)$. 
Lamiaa Abdel-Latif et al.

\subsection{Serum ferritin levels:}

The mean level of ferritin of the nonHCC patients was $120.9 \pm 108 \mu \mathrm{g} / \mathrm{dL}$ and that of HCC patients was $239.7 \pm 128 \mu \mathrm{g} / \mathrm{dL}$ which was statistically significantly higher in sera of HCC patients compared with that of non-HCC patients $(\mathrm{P}<0.0001$, Table 4).
4.3. Serum TIBC levels:

The mean serum level of TIBC of the non-HCC patients was $371 \pm 204.9 \mu \mathrm{g} / \mathrm{dL}$ and that of HCC patients was $596.8 \pm 216 \mu \mathrm{g} / \mathrm{dL}$. In general, TIBC of the HCC patients was found to be highly significantly increased than that of the non-HCC patients $(\mathrm{P}=0.0001$, Table 4).

Table 4: Mean values of iron, ferritin and total iron binding capacity (TIBC) levels in sera of HCC patients versus those of non-HCC patients.

\begin{tabular}{cccclc} 
Parameters & \multicolumn{3}{c}{ Non-HCC patients } & \multicolumn{2}{c}{ HCC patients } \\
\cline { 2 - 6 } & $\mathbf{N}$ & Mean \pm SD & N & \multicolumn{3}{c}{ Mean \pm SD } \\
Iron & 89 & $173.3 \pm 25.3$ & 22 & $203 \pm 30.6$ & $\mathrm{P}<0.0001$ \\
Ferritin & 104 & $120.9 \pm 108$ & 22 & $239.7 \pm 128$ & $\mathrm{P}<0.0001$ \\
TIBC & 44 & $185.5 \pm 102.4$ & 22 & $298.4 \pm 108.1$ & $\mathrm{P}<0.0001$ \\
\hline
\end{tabular}

Values were expressed as mean \pm standard deviation (mean \pm SD), $n=$ number, $\mathrm{p}=$ probability (Significance Level) when the results of patients with hepatocellular carcinoma (HCC) were compared to those of the healthy control group.

5. Liver function markers, platelets and alpha-fetoprotein (AFP) levels in sera of HCC patients and non-HCC patients:

The mean activities of liver enzymes, total bilirubin and AFP levels were statistically and significantly elevated in the blood of HCC

On contrary, the mean level of serum albumin and count of platelets were significantly decreased $(\mathrm{P}<0.0001$, Table 5).

Table 5: Mean values of the liver function markers, platelets count and alpha-fetoprotein (AFP) levels in sera of HCC patients versus those of non-HCC patients

\begin{tabular}{cccccc}
\hline Parameters & \multicolumn{2}{c}{ Non-HCC patients } & \multicolumn{3}{c}{ HCC patients } \\
\cline { 2 - 6 } SGPT & $\mathbf{N}$ & Mean \pm SD & $\mathbf{N}$ & \multicolumn{2}{c}{ Mean \pm SD } \\
SGOT & 88 & $52.0 \pm 26.8$ & 21 & $64.8 \pm 38.6$ & $\mathrm{P}=0.07$ \\
S. Albumin & 98 & $45.8 \pm 22.1$ & 22 & $82.7 \pm 31.7$ & $\mathrm{P}<0.0001$ \\
Total Bilirubin & 103 & $4.2 \pm 0.5$ & 22 & $3.6 \pm 0.6$ & $\mathrm{P}<0.0001$ \\
Platelets count & 104 & $0.9 \pm 0.53$ & 21 & $1.4 \pm 0.9$ & $\mathrm{P}<0.0009$ \\
Alpha fetoprotein & 43 & $9.4 \pm 1.8$ & 22 & $168.1 \pm 81.5$ & $\mathrm{P}<0.0001$ \\
\hline
\end{tabular}

Values were expressed as mean \pm standard deviation (mean \pm SD), $n=$ number, $p=$ probability (Significance Level) when the results of patients with hepatocellular carcinoma (HCC) were compared to those of the healthy control group.

6. Correlation of total microRNA-cDNA and viremia with iron status and alpha fetoprotein in sera of all patients with chronic hepatitis $\mathrm{C}$ :

As shown in table 6, no significant correlations were found between total microRNA-cDNA and viremia with iron status and alpha fetoprotein in sera of all patients with chronic hepatitis $\mathrm{C}$. 
Can Serum Iron Parameters Represent Surrogate Markers for Chronic Hepatitis C-Based Hepatocellular Carcinoma?

Table 6: Correlation of total microRNA-cDNA and viremia with iron status and alpha fetoprotein in sera of all patients with chronic hepatitis $C$

\begin{tabular}{ccc}
\hline Parameters & Total RNA-cDNA & Log_PCR \\
\hline Iron & 0.03 & -0.12 \\
Correlation Coefficient & 0.8 & 0.33 \\
Significance Level & 67 & 67 \\
Sample size & & \\
Ferritin & 0.03 & -0.1 \\
Correlation Coefficient & 0.79 & 0.4 \\
Significance Level & 70 & 80 \\
Sample size & & \\
TIBC & 0.19 & 0.1 \\
Correlation Coefficient & 0.13 & 0.58 \\
Significance Level & 64 & 51 \\
Sample size & & \\
Alpha fetoprotein (AFP) & -0.013 & -0.19 \\
Correlation Coefficient & 0.91 & 0.22 \\
Significance Level & 83 & 46 \\
Sample size & & \\
\hline
\end{tabular}

\section{DISCUSSION}

In the present study, iron excess was shown in sera of both $\mathrm{CHC}$ patients with HCC as well as in sera of non-HCC patients" group. The excess serum iron load in this study, confirms those which were reported by Fujita et al. (2007) who found excess hepatic iron in sera of patients with chronic hepatitis C. On contrary, Emerit et al. (2001) reported that, the causative factors of iron overload in the presence of the virus are not known.

The results of the present study confirm those of Siregar and Maail (2018) who found an increase in hepatic iron accumulation and iron related serum markers elevation. In the current study, the reduction in serum TIBC may be one of the causative factors of serum iron loading. This overload necessitates hepatic saturation with ionized iron. Therefore, one can render the progression of liver disorders to the relatively common oxidative stress mediated by the products of Fenton reaction (Fenton,
1894). This reaction produces hydroxyl radicals which initiate other radical reactions that will ultimately damage the liver cells (Khare and Garg, 2015). In this regard, Siregar and Maail, (Siregar and Maail, 2018) argue the increase in oxidative stress for the increment in iron loading in their patients. These increases strongly favor DNA damage, genetic instability, and tumorigenesis which are already the case in the present study. In this regard, iron loading was correlated with the parameters of liver function tests which reflects hepatic cellular inflammation, cellular membrane perforation with subsequent enzymatic elevations. The latter's enzymatic elevations reflects the severity of hepatic inflammation. The reduction in platelets formation, synthetic function (albumin) retardation and bilirubin elevations reflect liver cirrhosis and/or hepatic fibrogenesis and liver cells tumorigenesis in patients with chronic hepatitis $\mathrm{C}$ in the present study. Indeed, the results of Shibutani et al. (1991) Showed a 


\section{Lamiaa Abdel-Latif et al.}

significant correlation between 8-hydroxy-2'-deoxyguanosine (8-OHdG), a marker of oxidatively generated DNA damage, and iron loading.

In the present study, dramatic increases in both iron and ferritin were reported in sera of $\mathrm{HCC}$ patients than those in sera of non-HCC group. On contrary, transferring activity; as was reflected by TIBC was decreased with the increase in serum load of iron and ferritin. This may be due to the decrease in TIBC. Such decrease can leave ionized iron to be available for excessive production of free radicals with subsequent formation of oxidative stress, DNA modification and initiation of hepatocarcinogenesis. (Siregar and Maail, 2018; Shibutani et al., 1991). Therefore, one can suggest that iron loading and oxidative stress can also participate in reduction of hepcidin as was reported by Castagna et al. (2010) who also suggested that HCV infection in animal and in cellular models may directly modulate hepcidin expression via $\mathrm{HCV}$-induced reactive oxygen species (ROS). This mechanism can triggers further iron accumulation in $\mathrm{HCV}$ chronically infected patients. The HCVmediated TIBC is a key protein in iron metabolism, therefore its reduction in sera of the patients of the present study, and may also be hepcidin, can lead to iron deposition in the liver and/or higher levels of nontransferrin-bound iron in the blood stream (Hör and Schmidt, 2014). Since TIBC is a key protein in iron metabolism, one can expect that lowering of hepcidin level may leads to iron deposition in the liver and/or higher levels of non-transferrin-bound iron in the bloodstream (Hör and Schmidt,2014).

Milic et al. (2005) added that, liver disease decreases its synthetic functions; including, albumin and prothrombin-related proteins as well as hepcidin. Again, the nonbound iron mediates hydroxyl radicals flux and other reactive oxygen species (ROS). As a result, the phospholipids containing cell membrane will be undergo peroxidation, amino acid side chains oxidation, DNA breaks, and protein fragmentation. Taken together, iron-induced cellular damage may participate in hepatopathogenesis in patients with $\mathrm{HCC}$ on top of $\mathrm{CHC}$, as was reported in the present study. These results confirm that of Furutani et al. (2006) who reported importance of oxidative stress and subsequent mitochondrial injury synergistically induced by iron loading and HCV proteins in the development of HCC.

The beneficial effects of iron chelators and/or hepcidin antagonist administration on the pathogenesis of iron overloading in mouse models, lead one to confirm the participation of iron in liver pathogenesis. Also, Siregar and Maail (2018) showed that ferritin levels were increased with the progression of ChildPugh class $(p<0.001)$, i.e. with the increase in the severity of liver disease. The results of the present study confirm their findings in that the mean ferritin levels were increased in sera of patients with HCC than those of non-HCC. In 2015, Sekine et al. (2014) reported that $\mathrm{HCV}$ core protein up-regulates iron uptake into the mitochondria, and thus, exacerbates oxidative stress (lipid peroxidation and reduction in GSH and NADPH concentrations) as well as hepatic toxicity (Siregar and Maail, 2018). Since our patients are chronically infected with $\mathrm{HCV}$, one can expect the incorporation of viral proteins as well as viral RNA in iron loading, oxidative stress and hepatic toxicity; including HCC. This is the case in our patients, as viral RNA and miRNAcDNA did not differ among the two groups but those of iron markers did. These outhers added that, serum ferritin and transferrin levels seem to play an important role to determine the severity of liver fibrosis and necro-inflammatory activity. Nakano et al. (2018) added that core protein of HCV may 


\section{Can Serum Iron Parameters Represent Surrogate Markers for Chronic Hepatitis C-Based Hepatocellular Carcinoma?}

account for the susceptibility of HCVinfected individuals to develop porphyria cutanea tarda (PCT). In their study, high prevalence of $\mathrm{HCV}$ infection was found among patients with PCT. These mediate a simultaneous increase in iron overload, oxidative stress and enhancement of hepatic disorders including fibrosis, cirrhosis and/or HCC, a mechanism which may be expected in the present study.

These observations lead one to suggest that the induction of intracellular porphyrin metabolism via the core protein of HCV may account for the susceptibility of HCV-infected individuals to develop porphyria cutanea tarda (PCT) as was reported by Nakano et al. (2018). In their study, high prevalence of hepatitis $\mathrm{C}$ virus (HCV) infection was found among patients with PCT. These mediate a simultaneous increase in iron overload, oxidative stress and enhancement of hepatic disorders including fibrosis, cirrhosis and/or HCC, a mechanism which may be expected in the present study. In this regard, severe necroinflammatory activity; together with hepatic parenchymal disease was directly correlated with markers of iron status; namely serum iron, ferritin $(\mathrm{P}<0.001)$ and TIBC levels $(\mathrm{P}$ $<0.05)$ (Vagu et al., 2008).

A possible explanation for these elevations is that a necroinflammatory hepatic status can participate in the release of iron and ferritin from damaged hepatocytes, a process sustained also by the concomitant high serum activities of liver enzymes and lowering in albumin levels in sera of patients with HCC compared with those of non-HCC, in the present study (Price and Kowdley , 2009).Taken together, one can conclude that, the presence of viral proteins as well as viral RNA and/or microRNA, irrespective of their levels can participate in iron over load. The latter mediate HCC formation. Also, the role of viral molecules and/or micro-RNA in iron overload must not be neglected.

\section{REFERENCES}

Castagna, A.; Campostrini, N.; Zaninotto, F. and Girelli, D. (2010). Hepcidin assay in serum by SELDI-TOF-MS and other approaches. J. Proteomics, 73(3):527-536..

De Domenico, I.; Lo, E.; Ward, D.M. and Kaplan, J. (2009). Hepcidin-induced internalization of ferroportin requires binding and cooperative interaction with Jak2.Proc Natl Acad Sci (USA), 106(10): 3800-3805.

Dedania, B. and Wu, G.Y. (2015). Dermatologic Extrahepatic Manifestations of Hepatitis C. J. Clin. and Translational Hepatol., 3(2):127-33.

Emerit, J.; Beaumont, C. and Trivin, F. (2001). Iron metabolism, free radicals, and oxidative injury. Biomed. Pharmacother., 55:333-339.

Fenton, H.J.H. (1894). Oxidation of tartaric acid in presence of iron. J. Chem. Soc., 65: 899-910.

Franchini, M.; Targher, G.; Capra, F.; Montagnana, M. and Lippi, G. (2008).The effect of iron depletion on chronic hepatitis $\mathrm{C}$ virus infection. Hepatol. Int.,2(3):335-40.

Fujita, N.; Horiike, S.; Sugimoto, R., et al. (2007). Hepatic oxidative DNA damage correlates with iron overload in chronic hepatitis C patients. Free Radic. Biol. Med., 42: 353-362.

Furutani, T.; Hino, K.; Okuda, M. et al. (2006).Hepatic iron overload induces hepatocellular carcinoma in transgenic mice 


\section{Lamiaa Abdel-Latif et al.}

expressing the hepatitis $\mathrm{C}$ virus polyprotein. Gastroenterology, 130: 2087-2098.

Hör, W.H. and Schmidt, A. (2014). Low hepcidin triggers hepatic iron accumulation in patients with hepatitis C. Nephrol. Dial Transplant., 29(6):1141-1144.

Jaroszewicz, J.; Rogalska, M.; Flisiak, I. and Flisiak, R. (2010). Successful antiviral therapy is associated with a decrease of serum prohepcidicin in chronic hepatitis C. World. J. Gastroenterol., 16(14): 1747-1752.].

Khare, S. and Garg, V.K. (2015). Serum iron and TIBC parameters in chronic liver disease, Scholars Journal of Applied Medical Sciences (SJAMS) , 3(5E):2128-2131.

Kohgo, Y.; Ikuta, K.; Ohtake, T.; Torimoto, Y. and Kato, J. (2007). Iron overload and co-factors with special reference to alcohol, hepatitis $\mathrm{C}$ virus infection and steatosis/insulin resistance. World $\mathrm{J}$. Gastroenterol. ,13:4699-4706

Lavanchy, D. (2011). Evolving epidemiology of hepatitis $\mathrm{C}$ virus. Clin Microbiol Infect, 17(2): 107115.].

Metwally, M.A.; Zein, C.O. and Zein, N.N. (2004).Clinical significance of hepatic iron deposition and serum ron values in patients with chronic hepatitis C infection. Am J. Gastroenterol., 99(2):286-91.

Milic, F.; Mikolasevic, I.; Orlic, L.; Devcic, E.; Starcevic-Cizmarevic, N.; Stimac, D.; Kapovic, M. and Ristic, S. (2016). The Role of Iron and Iron Overload in Chronic Liver Disease. Med. Sci. Monit., 22: 2144-2151

Nakano, T.; Moriya, K.; Koike. K. and Horie, T. (2018). Hepatitis C virus core protein triggers abnormal porphyrin metabolism in human hepatocellular carcinoma cells. PLoS ONE, 13(6): e0198345.)

Price, L. and Kowdley, K.V. (2009).The role of iron in the pathophysiology and treatment of chronic hepatitis C. Can. J. Gastroenterol., 23(12):822-828.

Saito, H.; Fujimoto, Y.; Ohtake, T.; Suzuki, Y.; Sakurai, S.; Hosoki, Y.; Ikuta, K.; Torimoto, Y. and Kohgo, Y. (2005). Up-regulation of transferrin receptor 1 in chronic hepatitis $\mathrm{C}$ : Implication in excess hepatic iron accumulation. Hepatol Res., 31:203210.

Sekine, S.; Ito, K.; Watanabe, H.; Nakano, T.; Moriya, K.; Shintani, Y.; et al. (2015). Mitochondrial iron accumulation exacerbates hepatic toxicity caused by hepatitis $\mathrm{C}$ virus core protein. Toxicology and applied pharmacology, 282(3):237-43. Epub 2014/12/30. pmid:25545986.

Shibutani, S.; Takeshita, M. and Grollman, A.P. (1991). Insertion of specific bases during DNA synthesis past the oxidation-damaged base 8-oxo-7hydrodeoxyguanosine oxodG). Nature, 349: 431-434.

Siregar, G.A. and Maail, W. (2018). Serum iron parameters in liver cirrhosis. Earth and Environmental Science, 125(1):012217.

Uchino, K.; Tateishi, R.; Fujiwara, N.; Minami, T.; Sato, M.; Enooku, K.; et al. (2016). Impact of serum ferritin level on hepatocarcinogenesis in chronic hepatitis $\mathrm{C}$ patients. Hepatology research: the official journal of the Japan Society of Hepatology, 46(4):259-268. 


\section{Can Serum Iron Parameters Represent Surrogate Markers for Chronic Hepatitis C-Based Hepatocellular Carcinoma?}

Uchino, K.; Tateishi, R.; Nakagomi, R.; Fujiwara, N.; Minami, T.; Sato, M.; et al. (2018). Serum levels of ferritin do not affect the prognosis of patients with hepatocellular carcinoma undergoing radiofrequency ablation. PLoS ONE, 13(7): e0200943.

Vagu, C.; Sultana, C. and Ruta, S. (2013).Serum iron markers in patients with chronic hepatitis $\mathrm{C}$ infection. Hepatology Monthly, 13(10): e13136.
Walker, N.M.; Stuart, K.A.; Ryan, R.J.; Desai, S.; Saab, S.; Nicol, J.A. and Crawford, D.H.G. (2010). Serum ferritin concentration predicts mortality in patients awaiting liver transplantation. Hepatol., 51(5) 1683-91.

Zhou, X.D.; Stahlhut, M.W.; Hann, H.L. and London, W.T. (1988). Serum ferritin in hepatocellular carcinoma. Hepatogastroenterology, 35(1):1-4.

\footnotetext{
هل يمكن ان تمثل دلالات الحديد فى مصل الام دلالات بديلة لسرطان الكبد القائم على وجود التهاب كبدى مزمن س؟

لمياء عبد أللطيف1 ، جمال ألسيد شيحة2 ،3 ، وليد سمير4 ، ألثحات أبومسلم طوسون1 1

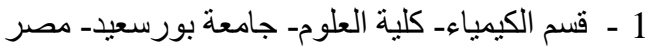

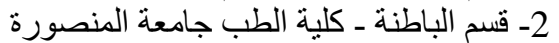

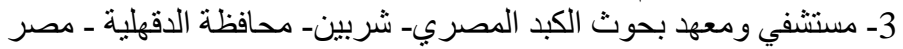

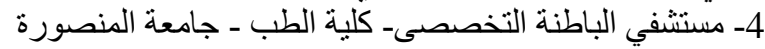

يلعب تتظيم مستوي الحديد فى الجسم دور ارئيسيا في حياة الانسان. وحتى الان فان الاثار الضاره لتر اكم الحديد بسبب الاصبابة

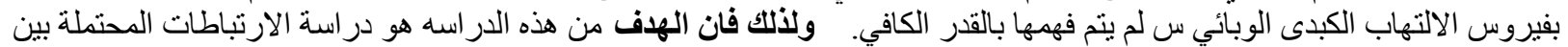

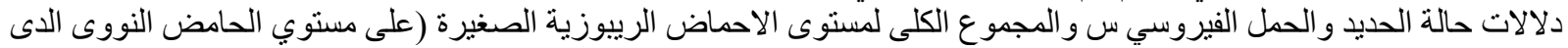

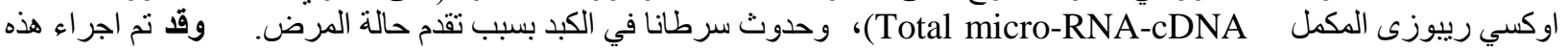

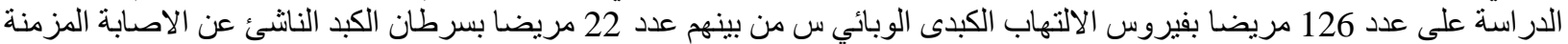

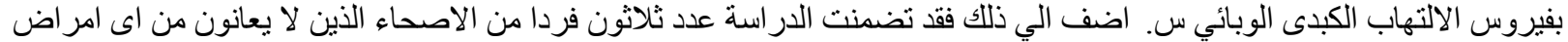

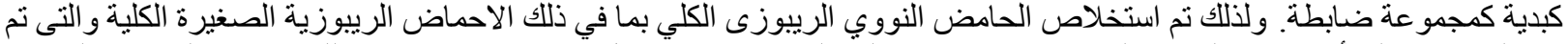

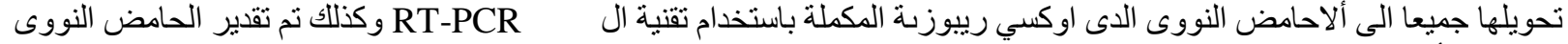

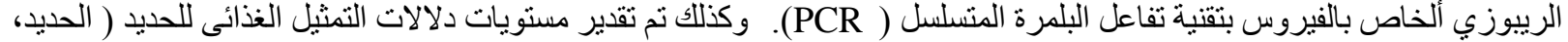
الفيريتين و القدرة الكلية للارتباط بالحديد ( TIBC). كما تم تقدير مستوي الالفا_فيتوبروتين ـ كدلالة اورام - وتقييم وظائف ألكبد وزمن البروثرومبين - ومنه تم حساب قيمة international normalization ratio، المقابلة. و وايضا تم عمل عد للصفائح

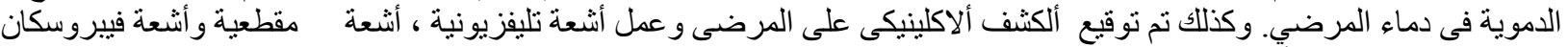

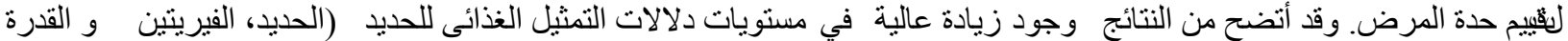

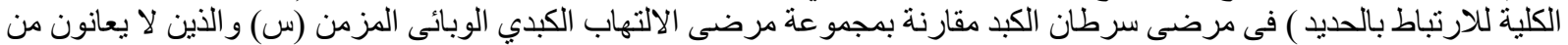

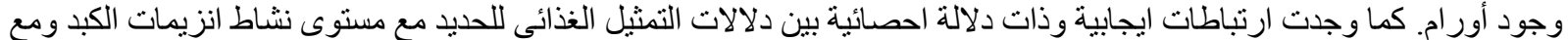

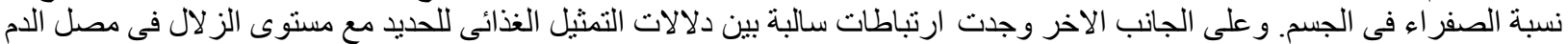

و عدد الصفائح الدموية فى الدم ككل (Whole blood). و وعلى العكس ، فقد وجد ان المجموع الكلى لمستوى الاحماض الريبوزية الصغيرة (Total micro-RNA-cDNA) وكذلك الحامض النووى الريبوزي الخاص بالفيروس (HCV-RNA) لا يرتبطا ارنباطات

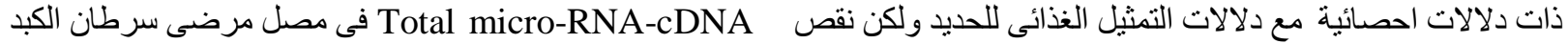

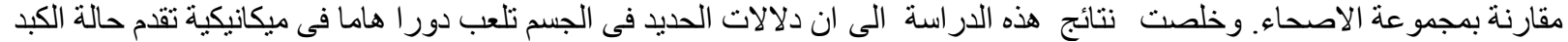

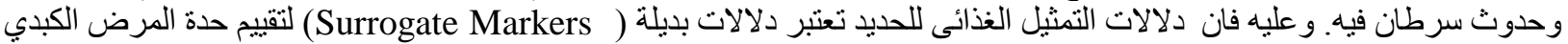

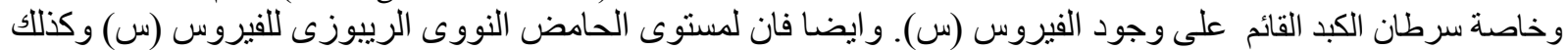

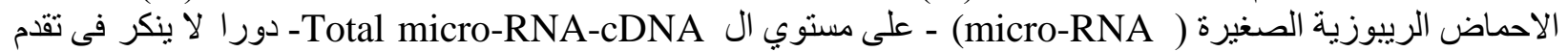

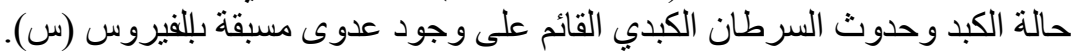

